J. clin. Path. (1951), 4, 316.

\title{
PARADOXICAL EMBOLISM
}

\author{
BY \\ B. I. JOHNSON \\ From the Division of Laboratories, Radcliffe Infirmary, Oxford
}

(RECEIVED FOR PUBLICATION SEPTEMBER 11, 1950)

The term "paradoxical embolism" was coined by Zahn* in 1885 to describe a condition in which emboli derived from the systemic venous system reached the systemic arterial system, by virtue of an abnormal communication between the chambers of the heart.

Three such cases have been observed at necropsy at the Radcliffe Infirmary, and they are considered worthy of record in so far as they illustrate the natural history of the disease, and one of them adds to the list of those in which the diagnosis cannot be doubted.

In 1877 Cohnheim described a case which was almost certainly one of paradoxical embolism. Some writers have mentioned earlier case reports which they consider to have been examples of the condition, but it is universally agreed that Cohnheim was the first to trace the path of an embolus through a septal defect in the heart, and it seems that these earlier reports must be regarded as open to question. Even now the diagnosis must usually be a presumptive one, and it would appear difficult to make it with certainty unless the embolus could actually be found passing through the septal defect. But it was not long after Cohnheim's report that this was in fact observed. Zahn, in 1881, reported a case in which necropsy revealed thrombosis in the uterine vein, multiple systemic emboli, and a patent foramen ovale in which lay a branched thrombus. It must be admitted that there were some small thrombi adherent to the wall of the left ventricle, so that the systemic emboli may perhaps not have passed through the foramen ; but even so, this case remains an example - the first of its kind - of a paradoxical embolus "caught red-handed." In the subsequent literature there are over 80 recorded cases of paradoxical embolism. After examination of the original reports, it was felt that the diagnosis in a few of these was insufficiently established, but a further 39 case reports have been found in which the embolus lay in situ in the foramen ovale (Table I). Presumptive cases,

\footnotetext{
* Thompson and Evans (1930), without giving a reference, stated that the term was suggested by von Recklinghausen, and this has been accepted by other writers. Zahn (1881) described his first case as one of " consecutive embolism," and Rostan (1884), one of Zahn's assistants, proposed the term "l'embolie croisée" in his doctorate thesis. Zahn (1885) rejected this and suggested "paradox embolie" in a paper which corrects some of the errors of Rostan's review, and in the same year von Recklinghausen (1885) put forward his theory of retrograde venous and lymphatic transport of malignant emboli ; in a subsequent paper Zahn (1889) upholds his introduction of " paradoxical embolism " and discusses von Recklinghausen's paper. Welch (1899) used "aberrant embolism" for Zahn's paradoxical embolism and von Recklinghausen's retrograde embolism. Ohm (1907) correctly attributed the term "paradoxical embolism" to Zahn.
} 


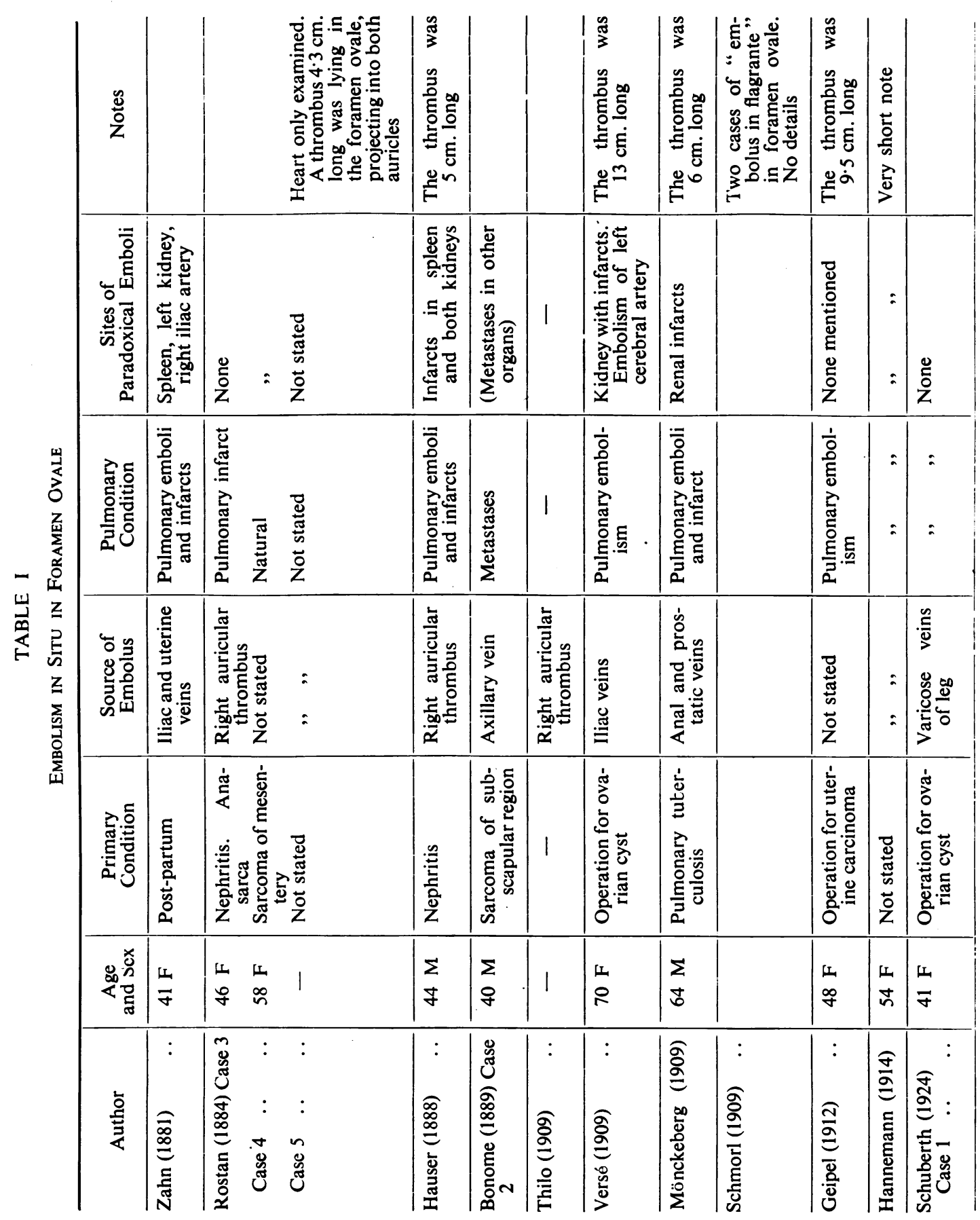




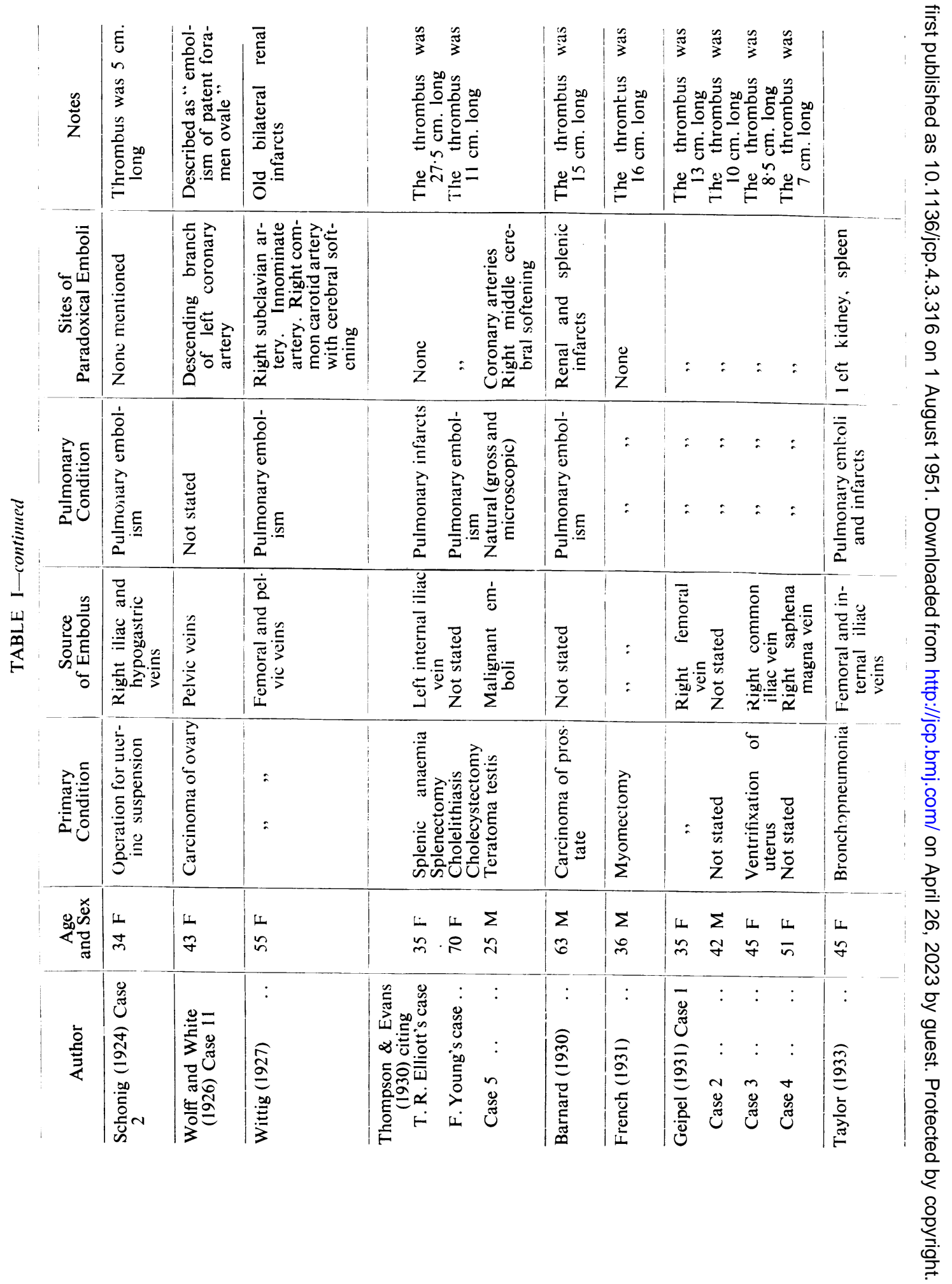




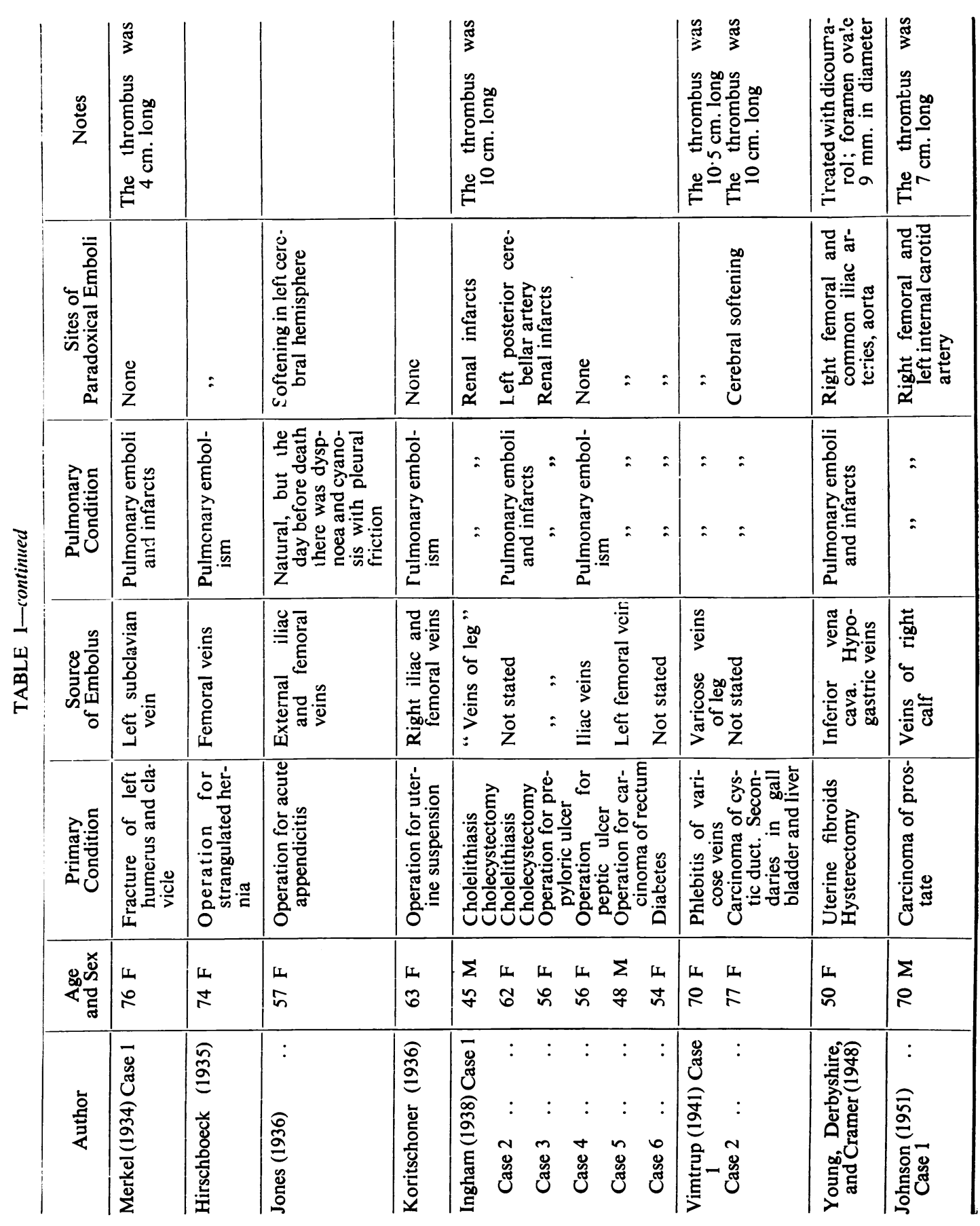


though doubtless more common, are less striking, but a further 43 case reports were found in which the diagnosis appeared to be virtually certain (Table II).

The case reports which have been rejected are those of Firket (1890), Buhlig (1904), Schmorl (1909), Dietrich (1925), and Armand-Delille and Lesobre (1935).

Firket's (1890) four cases showed fibrinous clots passing through a patent foramen ovale, but there were no emboli in the arterial system, no venous thromboses, and only in one case (Case I) was there a pulmonary infarct and that was associated with mitral and aortic stenosis. Buhlig's (1904) case report deals with a case of miliary tuberculosis in which the foramen ovale was patent, and he suggested that embolization of tuberculous material from a primary abdominal focus took place through the interauricular defect. Schmorl's (1909) case is of interest as he regarded it as an example of reversed embolism in which a portion of clot, formed on the walls of the left ventricle and extending down the aorta, passed through a patent foramen ovale and became lodged in the pulmonary arteries, but the account is very short.

Dietrich's (1925) case is difficult to assess. It was a patient aged 51 who had been in bed with thrombophlebitis of the leg for 11 weeks, and two days before death developed pain in the chest and hemiplegia ; at necropsy in addition to the changes in the leg vessels, the right jugular vein and transverse sinus were thrombosed, there were antemortem thrombi adherent to the wall of the right auricle, clots in the pulmonary artery, and a pencil patency of the foramen ovale; there was a thrombosis of the right carotid artery but no evidence of embolization. ArmandDelille and Lesobre (1935) reported a case of an 18-month-old child with a complex congenital heart lesion and hemiplegia who was found to have an interventricular septal defect as well as a patent foramen ovale and large friable vegetations on the mitral valve.

In addition there are a number of German inaugural dissertations which from their title deal with paradoxical embolism, but none were available in this country and the majority were not even to be found in abstract, so they only appear in the bibliography for the sake of completeness (Ems, 1907 ; Jaenicke, 1894 ; Kunkel, 1912 ; List, 1910 ; Müller, 1925 ; Poths, 1887 ; Scheven, 1894 ; Schmieden, 1888).

\section{Case Reports}

Case 1 (A. R.) Man Aged 70 (Reg. No. 75260/47). -The patient was admitted to hospital on July 27, 1947, with symptoms of urinary obstruction of seven weeks' duration. A diagnosis was made of carcinoma of the prostate gland, with multiple secondary deposits in the bones. Treatment with stilboestrol was instituted, but on July 31 catheterization and decompression were necessary. On the night of August 2 he had a small haemoptysis, and rales were heard at the base of the right lung. On August 3, while using a bedpan, he collapsed and was found to have a right-sided hemiplegia. He died on the following day.

At necropsy (P.M. 359/47) the diagnosis of prostatic carcinoma with skeletal secondaries was confirmed. The lungs were found to be very congested, and there was a recent haemorrhagic infarct in the right lower lobe ; the right pleural cavity contained about $300 \mathrm{ml}$. of clear, straw-coloured fluid. Branches of the pulmonary artery throughout both lungs contained thrombi, and a coiled cylindrical thrombus, $5 \mathrm{~mm}$. in diameter and $12 \mathrm{~cm}$. in length, lay astride its bifurcation, extending into both branches, particularly into the right. There was thrombosis of the deep veins of the right calf ; distally the thrombus was adherent to the veins, but the proximal end of it (which was in the popliteal vein) 
PARADOXICAL EMBOLISM

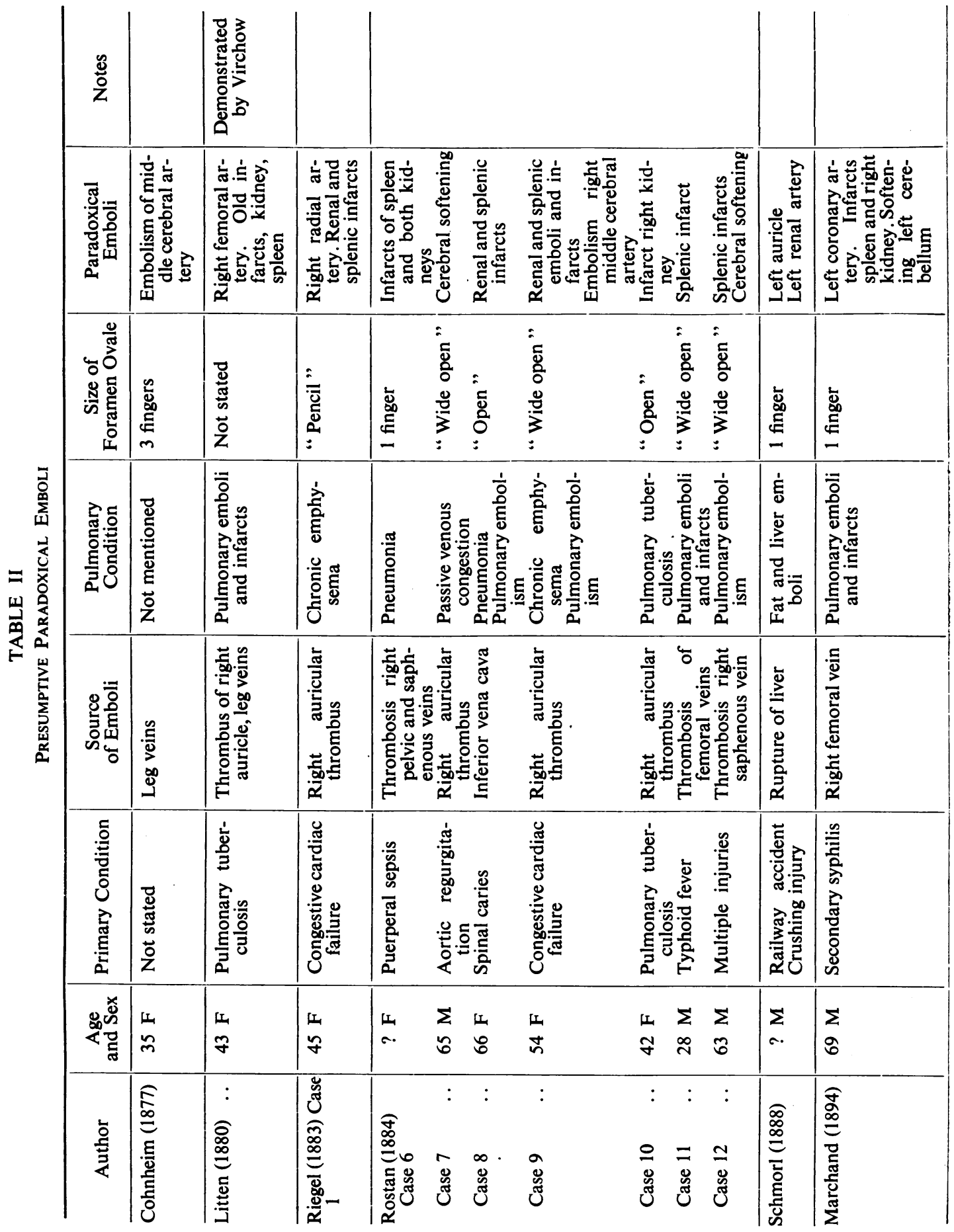




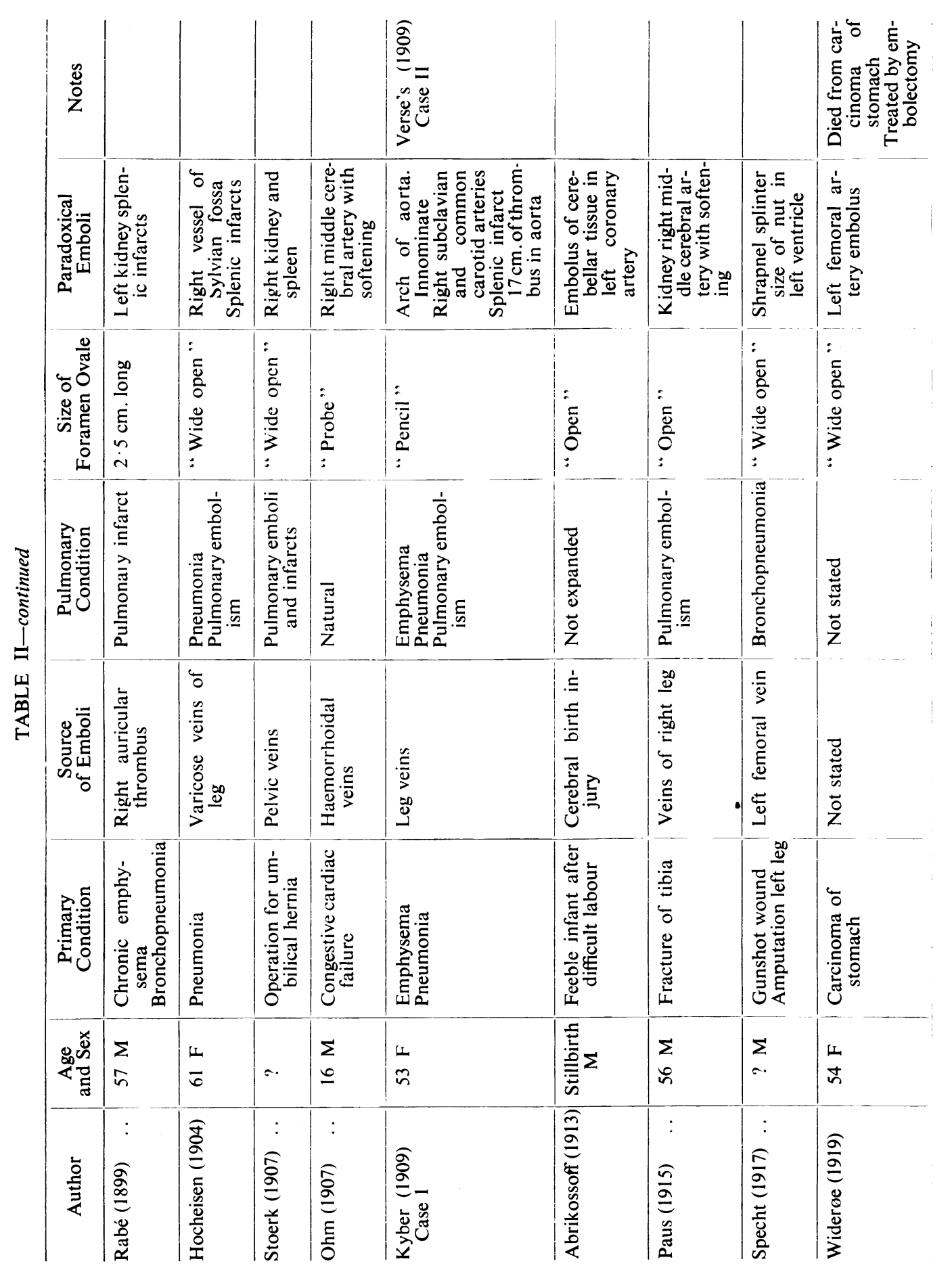




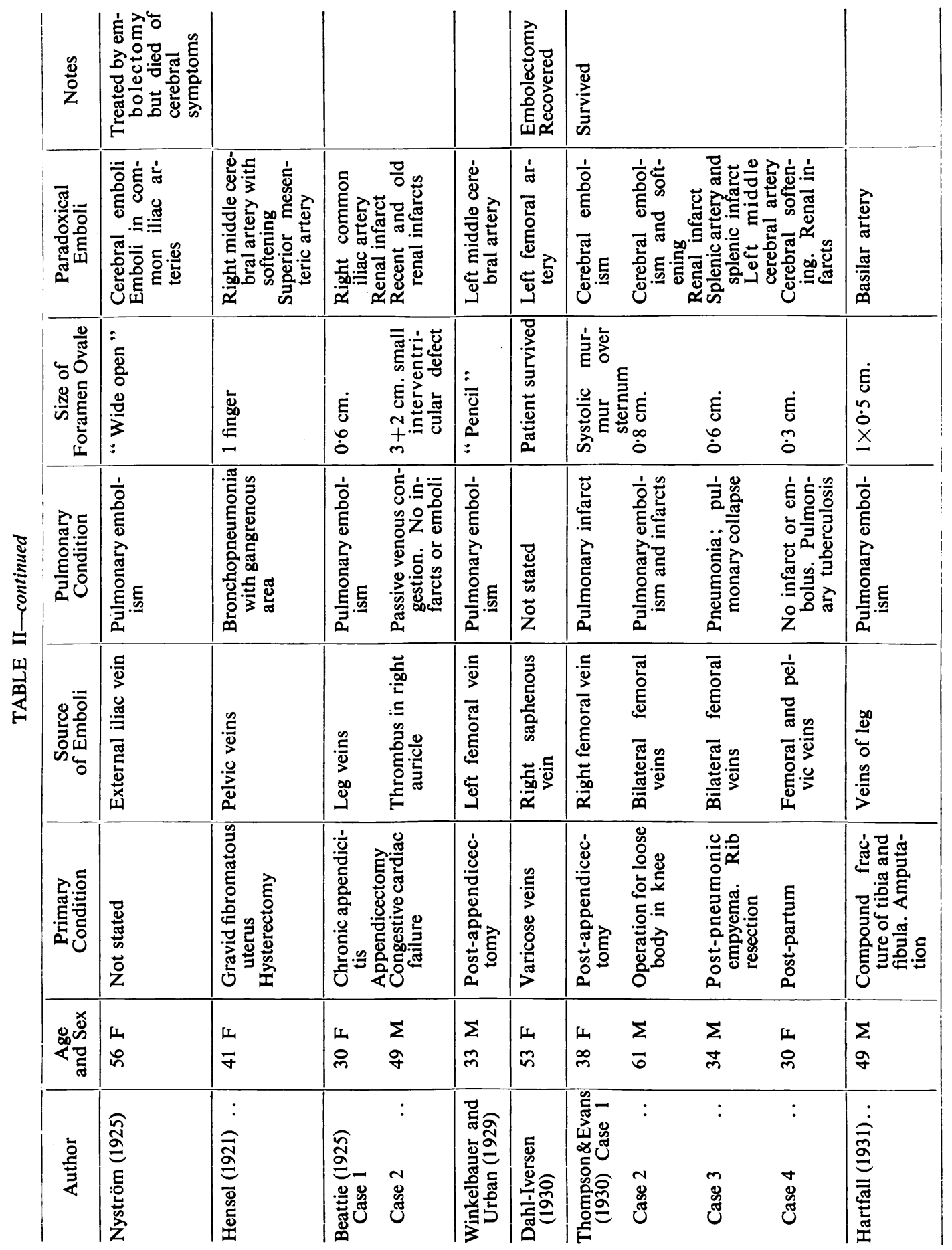


B. I. JOHNSON

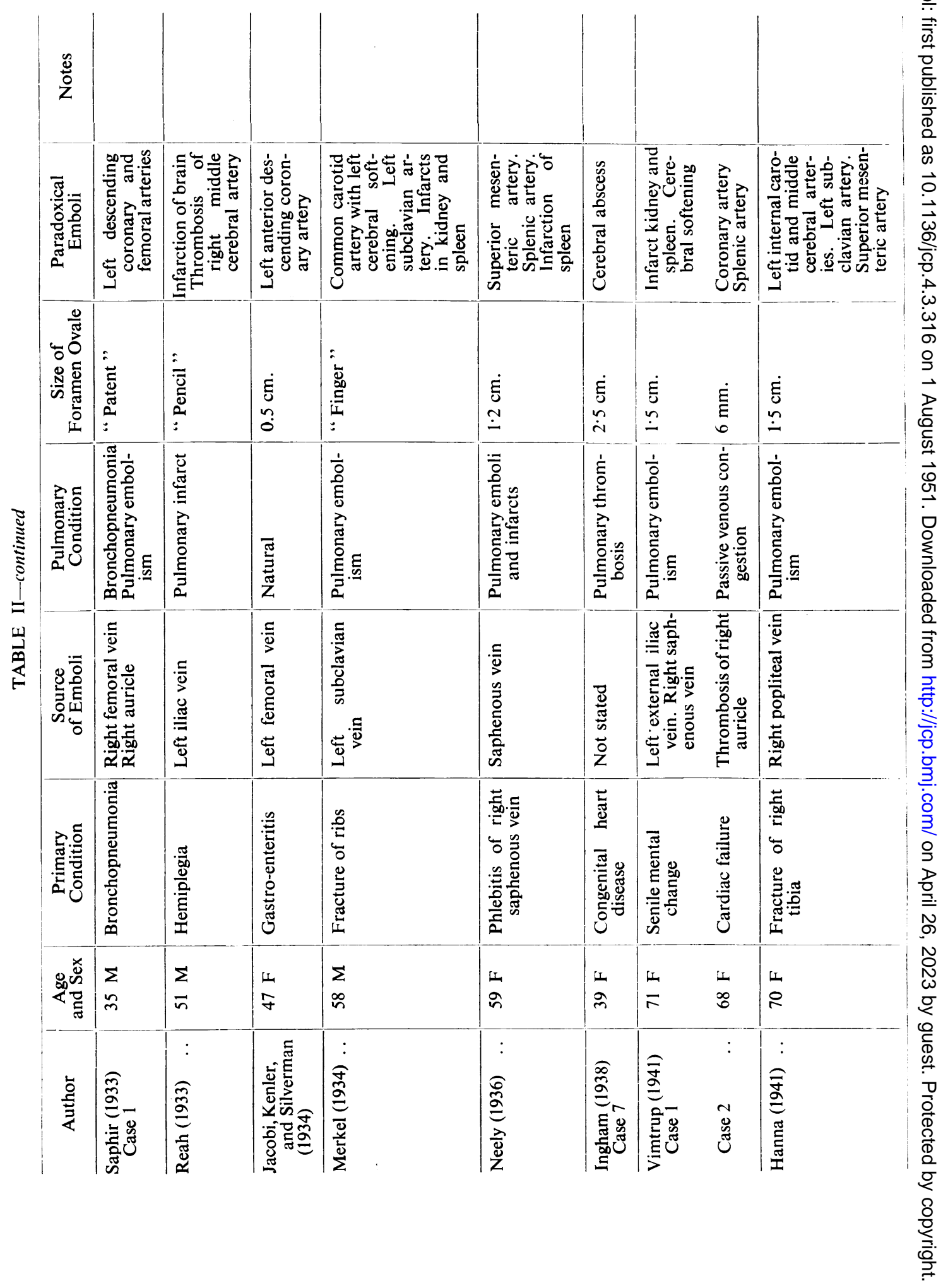




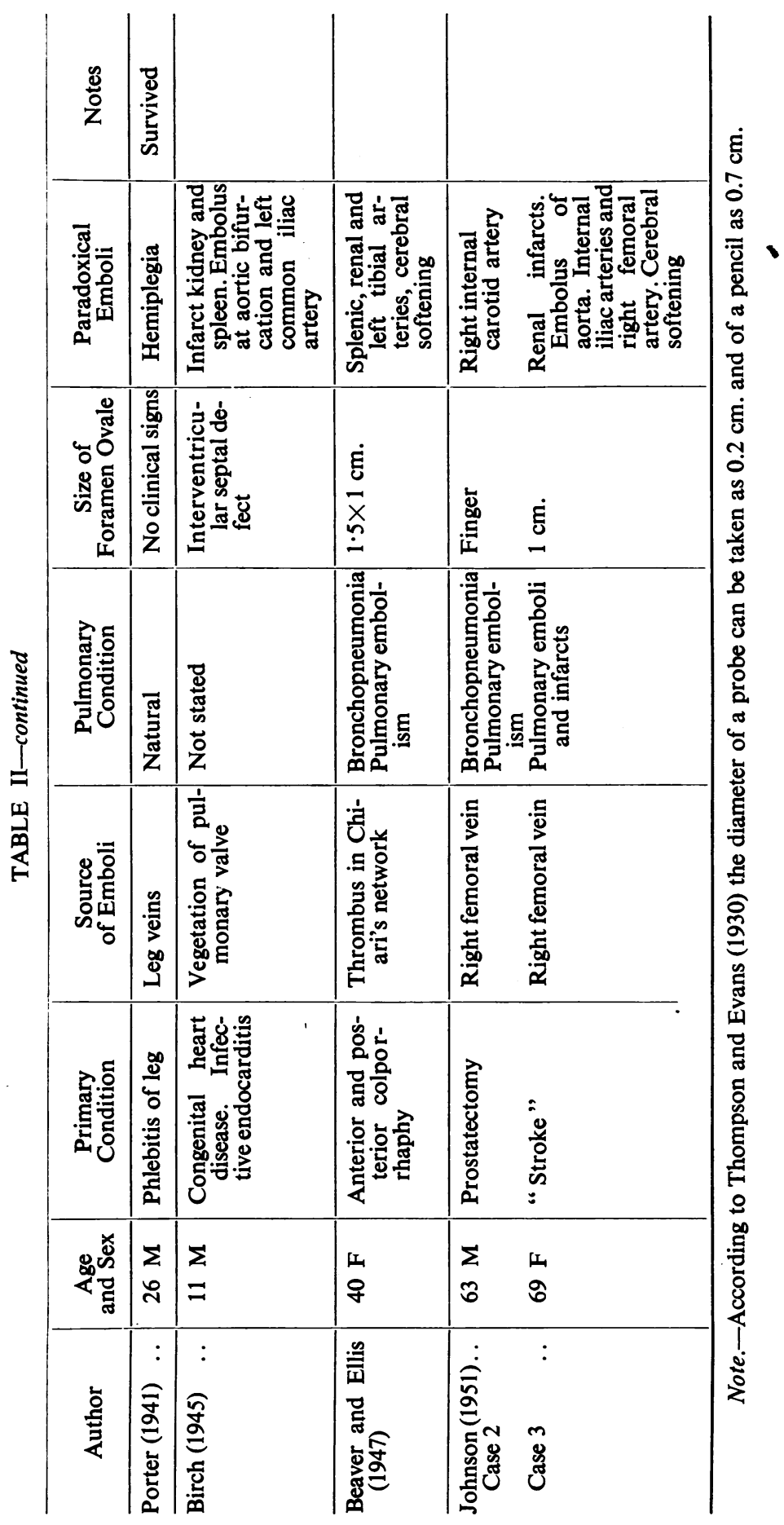




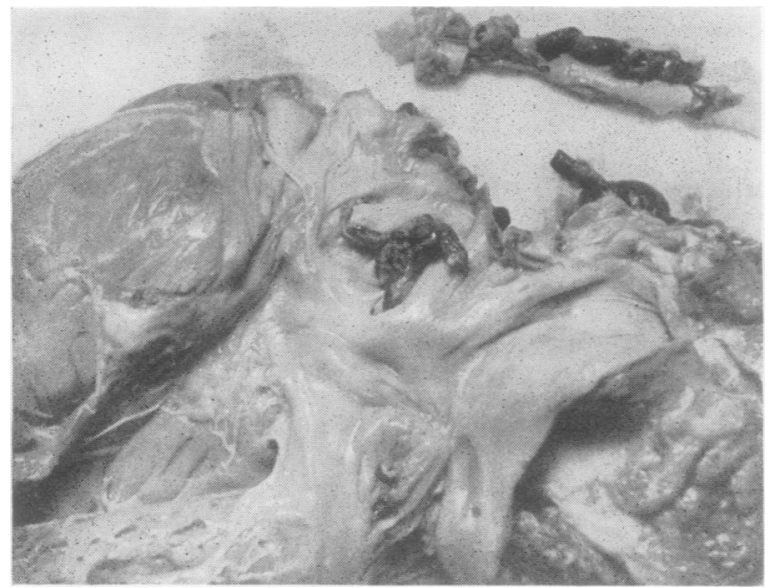

FIG. 1.-Right heart showing an embolus lying in the foramen ovale. The femoral artery containing an embolus can be seen in the upper right-hand corner of the photograph.

was lying free in the lumen, and showed a rough, blunt surface suggesting recent fracture. The heart showed no mural thrombosis. There was a valvular patency of the foramen ovale $5 \mathrm{~mm}$. in diameter, through which passed a cylindrical thrombus $7 \mathrm{~cm}$. in length : the main part of this thrombus lay in the right atrium, but one end presented as a coiled knot in the left atrium (Fig. 1). The right femoral artery contained a cylindrical embolus $5 \mathrm{~cm}$. long, just below the inguinal ligament, with secondary thrombosis distal to it ; the embolus was becoming adherent to the arterial wall. The left internal carotid artery was occluded at its bifurcation by a small embolus, distal to which the middle and anterior cerebral arteries were filled with clot.

Case 2 (E. N.) Man Aged 63 (Reg. No. 65755/47). - The patient stated that in 1920, when he was 36 years of age, he had had a right-sided paralysis which had incapacitated him for about three months, but which had subsequently cleared up completely. He was admitted to hospital on August 6, 1949, on account of difficulty of micturition ; cystoscopy was performed on August 8, and benign prostatic hyperplasia was diagnosed. His blood pressure was recorded on admission as 120/95. On August 10 he had a sudden onset of right-sided weakness while at stool ; he was found to have exaggerated reflexes on the right side, and an extensor right plantar response. Next day he was much better ; his blood pressure was now recorded as 170/110, and the incident was regarded as having been due to hypertensive encephalopathy. On August 15 a one-stage prostatectomy (Freyer) was carried out. After this the patient's condition remained satisfactory until September 8, when he collapsed again, with a left-sided flaccid paralysis, and clonic movements in the right arm. His condition deteriorated rapidly, and he died four days later.

At necropsy (P.M. No. 421/47) there was an antemortem thrombus in the right internal carotid artery, extending to the bifurcation, with corresponding cerebral softening. Both kidneys contained recent infarcts. Fragmented antemortem thrombi were found in the right femoral vein, the heart contained no mural thrombi, but there was a valvular patency of the foramen ovale, which admitted the forefinger. The lungs were congested and oedematous, and there was a considerable degree of bronchopneumonic consolidation; many of the smaller branches of the pulmonary artery in both lungs contained antemortem thrombi, but there were no corresponding infarcts.

This case appears to be of particular interest in that it is possible to explain the observed rise in blood pressure and the subsequent cerebral thrombosis as both being due to para- 
doxical embolism, the former to the renal infarcts. The nature of the neurological lesions causing the incidents of 1920 and of August 10, 1947, however, must remain very doubtful. It will be noted that Case 3 also contains the story of a transient "stroke" which likewise remains unexplained.

Case 3 (A. C.) Woman Aged 69 (Reg. No. 85923/48). - This patient was admitted to hospital on January 9,1949, following an attack of acute dyspnoea associated with the signs of occlusion of the right femoral artery. She had had four operations for genital prolapse and stress incontinence, the last being a "urethral sling" operation in October, 1948. In December she had had a mild "stroke," affecting the right side of the body and her speech. On January 2, 1949, she had had acute pain under the right breast (severe enough to require morphine), which had lasted on and off ever since. She stated that she had always been "chesty." On January 9 there was a sudden onset of dyspnoea and inability to move the right leg, and on admission on the same day she was found to have weakness of the left arm and signs in the right leg suggestive of a femoral embolus, but no abnormality was found in the respiratory or cardiovascular systems. She was treated with heparin, but bronchopneumonia supervened and she died on January 16.

At necropsy (P.M. 35/49) the left pulmonary artery was seen to be filled by a recent embolus ; the branch to the right lower lobe was occluded by a thrombus which was just starting to organize. The inferior vena cava and the right femoral vein and its branches contained antemortem thrombi. There was a valvular patency of the foramen ovale about a centimetre in diameter. There was an embolus just above the bifurcation of the aorta, with clot extending into both external iliac arteries and into the femoral artery on the right side; there were infarcts of both kidneys which were starting to organize, and, in the brain, numerous areas of punctate haemorrhage, with early cerebral softening. The appearance of these areas in the brain was considered to be compatible with the effests of multiple cerebral emboli ; the largest of them measured $3 \times 2 \times 1 \mathrm{~cm}$. and was situated at the upper part of the right post-Rolandic region.

\section{Discussion}

It is felt that these three cases fulfil the criteria for a diagnosis of paradoxical embolism. They all had patent foramina ovale and pulmonary emboli probably derived from phlebothrombosis of the leg veins; they all showed systemic arterial emboli without evidence of thrombosis in the left heart, and in the first case an embolus was seen lying in the foramen ovale at post-mortem examination.

In nearly all the convincing cases of paradoxical embolism, the cardiac lesion is a patent foramen ovale. For an embolus to pass through such an orifice, four conditions must be fulfilled. First, there must be a suitable source of embolic material in the venous circulation of the right heart. Secondly, there must be a patency of the foramen ovale of suitable size, and this is by no means uncommon. Patten (1938) found some degree of patency in $20 \%$ of 4,000 unselected necropsies. Thompson and Evans (1930) in an unselected series of 1,000 cases found $35 \%$ "probe patent" and $6 \%$ "pencil patent," but of these latter, over half the cases were under 6 months of age. Thus it would appear that at least $6 \%$ of the human race have an interatrial septal defect capable of transmitting a sizeable embolus. The fact that the majority of these foramina are valvular is not particularly important, in view of the third condition ; it is only necessary that they should be capable of transmitting an embolus from right to left.

"Two-way" patency is a relatively uncommon condition. Roesler (1934) gave a good review of 64 cases, in which he showed that although a number of the affected 
individuals have lived to a ripe old age, apparently unencumbered by a continual leak of blood from the right to the left heart, yet the average age at death was only 36 years. Three-quarters of them suffered from valvular disease of some sort, mitral disease being the commonest (the Lutenbacher syndrome first described by Maude Abbott in 1915). Further, the overloaded right ventricle was not normally capable of holding out indefinitely ; its ultimate failure gave rise to cyanosis-the cyanose tardive of Bard and Curtillet (1889)-and death. Unfortunately it is not always possible to gather from the recorded cases of paradoxical embolism which of the foramina were valvular and which were "two-way," but if, as is held by Beattie (1925), it is a fact that paradoxical embolism is more commonly found in association with "two-way" patency than with the valvular variety, then it is suggested that this is because such patencies tend to be larger and are therefore capable of transmitting a greater stream of blood, and because they are harder to overlook at necropsy, but not because they are "two-way."

Thirdly, for paradoxical embolism to occur through the foramen ovale, the pressure in the right atrium must be higher than that in the left. This may be caused, for instance, by any lesion capable of obstructing the pulmonary circulation, or by the cyanose tardive of the widely patent foramen ovale. But the most relevant and eminently likely cause in this connexion is pulmonary embolism. Zahn (1881) noted that paradoxical embolism was commonly preceded by pulmonary embolism ; and of the 41 cases in which the clot was in situ in the foramen ovale, at least 32 had pulmonary embolism or infarction; of the remaining nine, one (Jones, 1936) had the symptoms of pulmonary embolism during life, but none was found at necropsy ; in Thompson and Evans's case 5(1930) it is stated definitely that the lungs were normal macroscopically and microscopically, but, as this case was associated with malignant emboli, it is somewhat unusual ; Rostan's (1884) case 3 is also said to have had normal lungs, and Bonome's (1889) case showed pulmonary metastases; in the other five, the condition of the lungs was not specified. In Jones's case it is tempting, though perhaps a little fanciful, to postulate that pulmonary embolism did in fact occur, giving rise to a spasm of the pulmonary arterial system, which caused the embolus to pass back into the right atrium and through the patent foramen.

In the 46 presumptive cases, pulmonary embolism or infarction was present in 28 , absent in 13, and unknown in five, of which two cases survived the thromboembolic incident. Of the 13 cases in which pulmonary embolism or infarction was absent, four had pneumonia, three showed passive venous congestion, two had pulmonary tuberculosis, one showed chronic emphysema, and in one the lung was not expanded. There were two cases in which the lungs were stated to be natural; Ohm's (1907) case had a large "two-way" patency and had recently become cyanosed (presumably cyanose tardive), but Jacobi, Kenler, and Silverman (1934) are quite specific in their statement that both the lungs and the pulmonary arteries were natural. Thus in almost every case in which full information is available, there was some potential cause of raised right atrial pressure, by far the commonest being pulmonary embolism.

At this point some mention should be made of the often quoted work of Haggart and Walker (1923). They showed, in cats, that sudden occlusion of the left pulmonary artery for a matter of minutes produced no significant alteration in the systemic 
blood pressure but caused a rise in pulmonary arterial pressure averaging about $29 \%$ and seldom exceeding $33 \%$. Further, that up to about $63 \%$ of the total pulmonary arterial circulation could be occluded without signs of cardiac embarrassment, but that above this level dilatation and failure were rapid. Their work is a contribution of undoubted value to the study of pulmonary embolism, but it is felt that its relevance to the relative pressures in the atria of the human subject suffering from such an embolism has from time to time been over-emphasized.

Fourthly, given an embolus, a patent foramen ovale, and a flow of blood through the latter from right to left, there is still required that imponderable element of chance by which the embolus passes through the foramen instead of up the pulmonary artery with the residuum of the normal circulation. It seems reasonable to suppose that a patent foramen ovale would be instrumental in prolonging life in cases of massive pulmonary embolism by providing a much-needed shunt, and that the magnitude of the stream through it might well be as great as that through the pulmonary artery.

Up to now the discussion has been confined to paradoxical embolism through a patent foramen ovale. An interventricular septal defect would seem to present an equally tempting avenue to an itinerant embolus ; and, indeed, if pulmonary stenosis or dextraposition of the aorta were also present, an embolus arriving at the right heart would seem to stand an excellent chance of emerging by way of the aorta. However, only one really convincing case has been found in which an embolus has been demonstrated which must be presumed to have passed through such a defect. Birch (1945) describes the case of a boy aged 11 years, in whom a large vegetation from the tricuspid valve passed through an interventricular septal defect, and had become lodged at the bifurcation of the aorta. But the rarity of the interventricular defect as the offending lesion is not difficult to explain. Patency of the foramen ovale is far more common than the various complexes involving an interventricular defect, and this disparity becomes even greater as age advances, in so far as the latter constitute a greater threat to life. The average age of the undoubted cases of paradoxical embolism through the foramen ovale is 51, an age at which interventricular septal defects must be extremely rare, compared, on Thompson and Evans's (1930) figures, to the $1 \%$ of the populace of this age with a "pencil patency" of the foramen ovale. Zahn (1885) stated that at Geneva in the years 1882-4, in a consecutive series of 711 necropsies, a patent foramen ovale was found in $139(20 \%)$, and that in this period there were nine examples of paradoxical embolism (Rostan, 1884, Cases 3, 4, 6-12). In her analysis of 1,000 cases of congenital heart disease, Maude Abbott (1932) noted the occurrence of paradoxical embolism in 13 cases, but nine of these occurred amongst 90 cases in which patency of the foramen ovale was present. From these figures, it would seem that death may be associated with paradoxical embolism in $7-10 \%$ of cases of patent foramen ovale.

The association between major congenital heart disease and brain abscess has long been noticed. Farre records an instance in 1814, and Ballet, in 1880, drew attention to the association without guessing at its aetiology. It was Abbott, Lewis, and Beattie (1923) who first suggested that the occurrence of cerebral abscess in congenital heart disease might be due to paradoxical embolism, though the two cases they presented in support of this view are not altogether convincing. Hanna (1941) quotes 23 cases in which the conditions coincided, and Hand (1947) has collected 
36 cases. It seems difficult to escape the conclusion that these abscesses arise as a result of paradoxical embolism. Further, in a number of cases(Bach, 1928; Rabinowitz, Weinstein, and Marcus, 1932 ; Wechsler and Kaplan, 1940) in which a cerebral abscess occurred in association with septal defects, no source of an embolus could be found ; it seems reasonable to explain these on the hypothesis that minute emboli from unobtrusive septic foci (which would normally lodge in the lungs without causing symptoms) may in the presence of a "right-to-left shunt " cause a cerebral abscess.

Although it is possible to collect a fairly large number of such cases from the rather extensive literature on the subject, the condition cannot be regarded as a common one. In Maude Abbott's (1932) review there were only seven examples of cerebral abscess. Gates, Rogers, and Edwards (1947), out of 115 fatal cases of major congenital cardiac anomaly, had five cases of cerebral abscess, but Brown (1939) in over 100 cases of Fallot's tetralogy had only one such abscess. In Pennybacker and Sellors's (1948) series of over 100 cerebral abscesses, no case was found which might have been caused in this way.

In the past there had been much discussion as to the transmission of material, other than a thrombus, from the right to the left heart through a patent foramen ovale. Zahn (1885) was the first to suggest that tumour metastases might be spread by paradoxical emboli, but neither his cases nor those of subsequent writers can be included on the careful criteria insisted on by Thompson and Evans (1930), and indeed their own case 5 cannot be accepted without reserve ; Willis (1948) and Walther (1948) regard it as a rare and unimportant event in the dissemination of tumours. Schmorl (1888) described paradoxical embolism of liver tissue in a case of traumatic rupture of the liver, and less convincing examples have been recorded by Lubarsch (1893) and Flexner (1896) in cases of hepatic necrosis. Abrikossoff (1913) reported a stillborn child with birth injuries in which there was an embolus of cerebellar tissue in a coronary artery, and Specht (1917) found a fragment of shrapnel in the left ventricle of a soldier with a widely patent foramen ovale, who died following a gunshot wound of the leg. The possibility of fat and air embolism occurring through an intraauricular opening has also been discussed ; Fromberg (1913) has described cases of fat embolism of this type, and Steindl (1924)and Pamperl(1924)cases of air embolism, while the whole subject has been reviewed by Merkel (1934), but it must be confessed that the evidence presented in most of these cases is far from convincing.

\section{Summary}

Three cases of paradoxical embolism are recorded, in one of which there was a thrombus in situ in a patent foramen ovale ; 40 similar reports have been found, in which there was a clot in situ at necropsy. The mechanism of paradoxical embolism through the foramen ovale is discussed, and the various types reviewed.

Attention is drawn to the association between major congenital heart disease and cerebral abscess. It appears probable that such abscesses are caused by paradoxical embolism, sometimes by very small emboli from asymptomatic foci. The finding of an actual embolus that has travelled by this route is uncommon.

I am indebted to the medical staff of the United Oxford Hospitals for permission to publish these cases, and to Dr. A. H. T. Robb-Smith for his encouragement and advice. 


\section{REFERENCES}

Abbott, M. E. (1915). Int. Ass. med. Mus. Bull., 5, 129.

- (1932). "Congenital Heart Disease." Nelson Loose Leaf Medicine, vol. 4, p. 207. New York.

Lewis, D. S., and Beattie, W. W. (1923). Amer. J. med. Sci., 165, 636.

Abrikossoff, A. J. (1913). Zbl. allg. Path. path. Anat., 24, 244.

Armand-Delille, P., and Lesobre, R. (1935). Bull. Soc. P.diat. Paris, 33, 274.

Bach, F. (1928). Lancet, 1, 1009.

Ballet, G. (1880). Arch. gìn. Méd., 7 sér., 5, 659.

Bırd L., and Curtillet, - . (1889). Rev. Méd., Paris, 9, 9×3.

Barnard, W. G. (1930). Quart. J. Med., 23, 305.

Beattie, W. W. (1925). B.ll. int. Ass. med. Mus., 11, 64.

Beaver, D. C., and Ellis, S. W. (1947). Amer. J. clin. Path., 17, 866.

Birch, C. A. (1945). Brit. med. J., 2, 727.

Bonome, A. (1889). Arch. Sci. med., 13, 267.

Brown, J. W. (1939). Congenital Heart Disease. London.

Buhlig, W. H. (1904). Amer. J. med. Sci., 128, 992.

Cohnheim, J. (1877). 'Vorlesungen über allgemeine Pathoiogie, vol. 1, p. 144 . Berlin.

Dahl-Iversen, E. (1930). Lyon chir., 27, 39. (Also described by Dahl-Iversen, E., and Ramberg, E. (1932). Hospitalstidende, 75, 371.)

Dietrich, A. (1925). Virchows Arch., 254, 830

Ems, F. (1907). " Persistenz des Foramen ovale und paradoxe Embolie." Inaugural Dissertation, Munich.

Farre, J. R. (1814). Pathological Researches on Malformations of the Himan Heart. London.

Firket, C. (1890). Bull. Acad. Mid. Belg., 4 sér., 4, 85.

Flexner, S. (1896). Johns Hopk. Hosp. B'lll., 7, 171.

French, L. R. (1931). Arch. Path., 11, 383.

Fromberg, C. (1913). Mitt. Grenzgeb. Mrd. Chi"., 26, 23.

Gates, E. M., Rogers, H. M., and Edwards, J. E. (1947). Proc. Mayo C.in., 22, 401.

Geipel, P. (1912). Münch. med. Wschr., 59, 1683.

- (1931). Virchows Arch., 282, 67.

Haggart, G. E., and Walker, A. M. (1923). Arch. Surg., Chicago, 6, 764.

Hand, A. (1947). J. Pediat., 31, 662.

Hanna, R. (1941). Amer. J. Dis. Child., 62, 555.

Hannemann (1914). Dtsch. med. Wschr., 40, 202.

Hartfall, S. J. (1931). Lancet, 1, 700.

Hauser, G. (1888). Münch. med. Wschr. 35, 583.

Hensel, R. (1921). Dtsch. med. Wschr., 47, 625.

Hirschboeck, J. F. (1935). Amer. J. med. Sci., 189, 236.

Hocheisen, P. (1904). Fortschr. Med., 22, 393.

Ingham, D. W. (1938). Amer. J. med. Sci., 196, 201.

Jacobi, M., Kenler, M., and Silverman, I. (1934). Amer. Heart J., 9, 414.

*Jaenicke, O. (1894). " "Über das Foramen ovale cordis." Inaugural Dissertation, Kiel.

Jones, R. (1936). Brit. med. J., 2, 225.

Koritschoner, R. J. (1936). J. Amer. med. Ass., 106, 1269.

*Kunkel (1912). " Über Paradoxe Embolie." Inaugural Dissertation, Würzburg.

*Kyber, K. (1909). “Uber zwei Fälle von paradoxer Embolie.” Dissertation, Leipzig. (Abstract in Thorel (1911) and Versé (1909).)

*List, O. (1910). "Beiträge zur Kenntnis der Embolie bei offenem Foramen ovale." Inaugural Dissertation, Giessen.

Litten, M. (1880). Virchows Arch., 80, 281.

Lubarsch, O. (1893). Fortschr. Med., 11, 805.

Marchand, F. (1894). Berl. klin. Wschr., 31, 36.

Merkel, H. (1934). Dtsch. Z. ges. gerichtl. Med., 23, 338.

Mönckeberg, J. G. (1909). Dtsch. med. Wschr., 35, 1044.

*Müller, H. K. (1925). " Zur Kenntnis des embolischen und thrombotischen Verschlusses der Bauchaorta." Inaugural Dissertation, Marburg.

Neely, J. M. (1936). Neb. St. med. J., 21, 61 .

Nyström, G. (1925). Forh. 15 nord. kir. Fören., Copenhagen, p. 57. (Abstract in Vimtrup (1941).)

Ohm, J. (1907). Z. klin. Med., 61, 374.

Pamperl, R. (1924). Beitr. Klin. Chir., 132, 680.

Patten, B. M. (1938) Amer. J. Path., 14, 135.

* The original of this article has not been consulted. 
Paus, N. (1915). Dtsch. Z. Chir., 133, 383.

Pennybacker, J. P., and Sellors, T. H. (1948). Lancet, 2, 90.

Porter, A. G. (1941). Ibid., 2, 634.

*Poths, H. (1887). " Beiträge zur Casuistik der Embolie bei offenem Foramen ovale." Inaugural Dissertation, Giessen.

Rabé, M. (1899). Gaz. hebd. Méd. Chir., n.s. 4, 413.

Rabinowitz, M. A., Weinstein, J., and Marcus, I. H. (1932). Amer. Heart J., 7, 790.

Reah, T. G. (1933). Brit. med. J., 1, 142.

Recklinghausen, F. von (1885). Virchows Arch., 100, 503.

Riegel, F. (1883). Dtsch. Arch. klin. Med., 34, 233.

Roesler, H. (1934). Arch. intern. Med., 54, 339.

Rostan, A. (1884). "Contribution à l'étude de l'embolie croisée, consécutive à la persistance du trou de Botal." Thèse, Geneva. Rivera et Dubois.

Saphir, O. (1933). Amer. Heart J., 8, 312.

*Scheven, U. (1894). " "Zur Lehre von der atypischen Embolie." Inaugural Dissertation, Rostock.

*Schmieden, W. (1888). “ Über Verschleppung von Thromben-material, U.S.W." Inaugural Dissertation, Freiburg.

Schmorl, G. (1888). Dtsch. Arch. klin. Med., 42, 499.

_. (1909). Verh. dtsch. path. Ges., 13, 217.

Schonig, A. (1923-4). Beitr. Path. Anat., 72, 580.

Schuberth (1924). Wien. klin. Wschr., 37, 862.

Specht (1917). Münch. med. Wschr., 64, 892.

Steindl, H. (1924). Wien. klin. Wschr., 37, 206.

Stoerk, O. (1907). Ibid., 20, 1555.

Taylor, J. (1933). Arch. Path., 16, 901 (also described in Bull. Ayer clin. Lab., 1934, 3, 39).

Thilo, L. (1909). "Zur Kenntnis der Missbildungen des Herzens." Inaugural Dissertation, Leipzig (abstract in Thorel, 1911).

Thompson, T., and Evans, W. (1930). Quart. J. Med., 23, 135.

Thorel, C. (1911). Engebn. allg. Path. Bact. Anat., 14, 133.

Versé, M. (1909). Verh. dtsch. path. Ges., 13, 215.

Vimtrup, B. (1941). Nord. Med., 10, 1839.

Walther, H. E. (1948). Krebsmetastasen. Basel.

Wechsler, I. S., and Kaplan, A. (1940). Arch. intern. Med., 66, 1282.

Welch, W. H. (1899). System of Medicine, ed. by T. Clifford Allbutt, vol. 6, p. 228. London.

*Widerøe, S. (1919). Forh. 12 nord. kir. Fören., Christiania, p. 166. Lund. (Abstract in Vimtrup (1941).)

Willis, R. A. (1948). Pathology of Tumours. London.

Winkelbauer, A., and Urban, K. (1929). Wien. klin. Wschr., 42, 1072.

Wittig, M. (1927). Z. KreislForsch., 19, 505.

Wolff, L., and White, P. D. (1926). Boston med. Surg. J., 195, 13.

Young, R. L., Derbyshire, R. C., and Cramer, O. S. (1948). Arch. Path., 46, 43.

Zahn, F. W. (1881.). Rev. méd. Suisse rom., 1, 227. (1885). Dtsch. Z. Chir., 22, 1.

(1889). Virchows Arch., 115, 71.

* The original of this article has not been consulted. 